\title{
Oral care quality improvement intervention results in decreased ventilator associated pneumonia ratio and increased productivity
}

Y Kenmotsu

From 3rd International Conference on Prevention and Infection Control (ICPIC 2015)

Geneva, Switzerland. 16-19 June 2015

\section{Introduction}

Ventilator associated pneumonia (VAP) is associated with increased morbidity and mortality, increased length of stay, and excess costs. Effective VAP prevention requires multiple interventions, including compliance with an oral care regimen.

\section{Objectives}

A quality improvement (QI) initiative was implemented at a hospital in Japan to assess the effectiveness of a modified oral care regimen on the VAP ratio and caregiver productivity.

\section{Methods}

The QI initiative modified the standard of care for oral care provided to ventilated patients. During the "before" period, standard of care was every 8 hour oral care with toothpaste, toothbrush, and fresh water. During the "after" period, the QI intervention was oral care provided every 4 hours with Q-Care ${ }^{\circledR}$ (Sage Products LLC), consisting of a kit designed for cleaning, debriding, suctioning and moisturizing. Metrics compared included the VAP ratio and time consumption before and after the QI intervention.

\section{Results}

The QI intervention resulted in a 59\% reduction in VAP ratio from 2009 through 2011. The standard of care time consumption was 9.8 minutes per oral cleansing, compared with 5.7 minutes per oral cleansing with Q-Care ${ }^{\circledR}$.

\section{Conclusion}

The QI initiative resulted in a decreased VAP ratio and increased productivity.

ICU, Tokai university Hachioji Hospital, Tokyo, Japan

\section{Disclosure of interest}

None declared.

Published: 16 June 2015

\section{doi:10.1186/2047-2994-4-S1-P243}

Cite this article as: Kenmotsu: Oral care quality improvement

intervention results in decreased ventilator associated pneumonia ratio

and increased productivity. Antimicrobial Resistance and Infection Control 2015 4(Suppl 1):P243.
Submit your next manuscript to BioMed Central and take full advantage of:

- Convenient online submission

- Thorough peer review

- No space constraints or color figure charges

- Immediate publication on acceptance

- Inclusion in PubMed, CAS, Scopus and Google Scholar

- Research which is freely available for redistribution 